\title{
Een verhaal wat eintlik baie verhale vertel
}

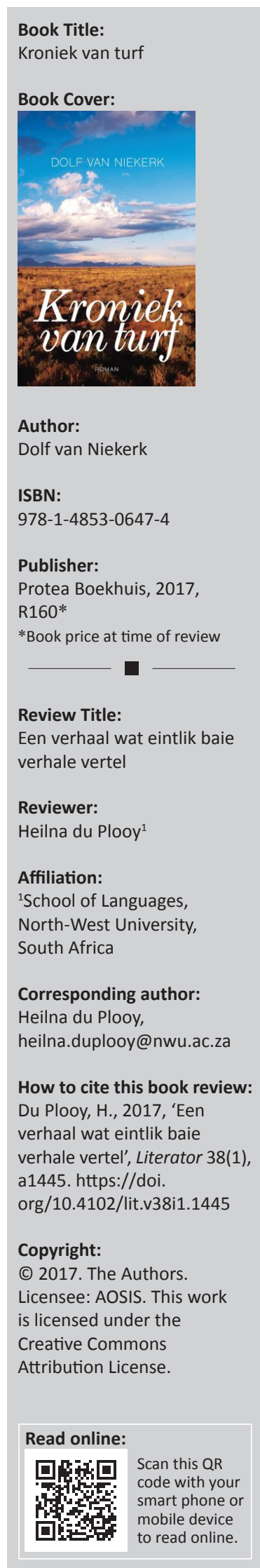

Dolf van Niekerk was een van die groep skrywers wat later as die Sestigers bekend sou staan en soos die ander skrywers van die groep, Jan Rabie, Etienne Leroux, André P. Brink en Chris Barnard asook die digter Breyten Breytenbach, is hy ' $n$ volhardende en toegewyde skrywer met ' $n$ lang skrywersloopbaan. Van Niekerk is in 1929 gebore en hy debuteer in 1958 met Gannavlei wat in 1960 gevolg word deur die baie bekende en hoog aangeskrewe Die son struikel. Van daar af publiseer hy gereeld elke jaar of drie, vier 'n boek sodat Kroniek van turf - as ek reg tel - sy 27ste boek is. Sy oeuvre bevat romans en novelles, kortprosa, dramas, jeugverhale en poësie, waaruit sy veelsydigheid blyk, en telkens ontlok sy werk opnuut waardering by kritici en lesers.

Vanuit 'n ander hoek beskou, is Van Niekerk ook een van daardie skrywers in Afrikaans wat tot op 'n gevorderde leeftyd aktief bly skryf. 'n Mens dink aan Miemie Rothmann (meer bekend as M.E.R.), Elisabeth Eybers, F.A. Venter, T.T. Cloete en ook ander skrywers wat miskien nie tot in hulle tagtigerjare of negentigerjare bly skryf het nie, maar wat wel aktief bly skryf het tot kort voor hulle afsterwe, soos Brink en Karel Schoeman. Dit is miskien 'n saak wat wyer bestudeer kan word, naamlik waarom dit so is dat daar soveel Afrikaanse skrywers is wat tot op hoë ouderdom bly skryf en ook baie goed bly skryf. Want op 88 skryf Van Niekerk steeds helder en deurdag en met insig.

Wat my opval, is dat ouer skrywers se werk 'n soort gestroopheid vertoon asof hulle inderdaad meer gerig is op die essensies van sake as die opstapeling van versiering, of ingewikkelde struktuur, of eksperimente met tegniek. Nie dat of estetiese vormgewing of struktuur of tegniek by Eybers of Cloete of Schoeman of enige ander van die genoemde skrywers ontbreek nie, allesbehalwe, maar daar is 'n fokus en gerigtheid asof die ervare oog en oor skerper kan deurkyk en deurhoor deur al die geruis van ons tydvak.

Kroniek van turf kan beskryf word as 'n historiese novelle of kort roman, maar die teks vertoon 'n duidelik eiesoortige karakter. Historiese literatuur kan baie vorme aanneem, van 'n breedopgesette rekonstruksie van 'n era met baie karakters en detail oor politieke, ekonomiese, sosiale en psigologiese omstandighede tot by 'n verskeidenheid klemplasings hetsy op individue teen die agtergrond van die geskiedenis of mense as die generators van historiese gebeure. Daar kan gekonsentreer word op bepaalde historiese gebeure as sodanig of die tipering van 'n tydperk, en die hantering van historiese stof kan deur fiksionalisering en selfs demonisering gekompliseer word.

Van Niekerk hanteer die historiese stof op 'n sober manier. Die verhaal van een familie word vertel, telkens deur te fokus op een persoon uit 'n generasie. Daar word 'n enkele lyn gevolg deur die geskiedenis oor bykans drie eeue heen. Daar word dus 'n enkele draad in die ryk tapisserie van die geskiedenis gevolg. Die verhaal begin met Gerrit in Veenwouden in Friesland waar die kerk van Johannes die Doper se toring bo die huise se dakke uitsteek en 'n bos van reus-eike die omgewing oorheers. Maar die mense kry swaar - hulle is pagters wat grondeienaars in die oë moet kyk en Gerrit soek iets anders as sy pa en oupa se lewe. Hy wil na die Cabo gaan, maar vry passaat word nie meer gegee nie en daarom word hy eers matroos om in die Kaap te kom en daarna werk hy vir vier jaar as kwartiermeester vir die Kompanjie. Daarna word hy veeboer in die Roggeland en hy noem sy plaas Uitkyk. En hier begin die eintlike verhaal van mense van Europese afkoms in Afrika. Daar is droogte wat die keel laat toetrek en die diere verswak en Gerrit moet met sy diere na die Karoo trek vir weiding. Dan reën dit weer en Gerrit gaan terug na Uitkyk. Hy trou, bou 'n huis en begin 'n gesin - dit word 'n lewe:

Skemeraande loop hy en Anna met Johannes langs die spruit wat snags 'n silwer streep in die maanlig lê. Hulle kyk opgewonde soos kinders na die huis wat soos 'n klein fort die dae en nagte trotseer. Die somer behandel hulle goed, maar die winter wat volg, is droog. (bl. 15)

Daar is wel deeglik probleme: Daar kom gereeld droogtes en erge koue, maar wat hulle veral kwel, is die mense wat onwettige landtogte en ruilekspedisies onderneem. Hulle pleeg onreg en 
veroorsaak aggressie en dan word daar op die boere wraak geneem. Wanneer Gerrit en Anna hulle eersteling, Johannes, in Stellenbosch gaan doop, word hulle huis afgebrand. Daarna trek hulle weg en begin opnuut op 'n leningsplaas aan die Buffeljagtsrivier. Die hartseer oor die lewe op Uitkyk word agtergelaat en hulle maak 'n nuwe lewe, maar spoedig is daar weer onrus en die Swellendammers gaan saam met 'n kommando van Stellenbosch na die Visrivier om die Xhosas te probeer terugdryf. Gerrit sterf in 'n konfrontasie aan 'n assegaaiwond en kort daarna sterf sy vrou ook. Daar word vir hulle saam 'n roudiens gehou:

Die dag is bewolk en vir Johannes is dit asof daar 'n wolk voor die son van hulle bestaan geskuif het.' $n$ Gevoel van vervreemding vat in hom pos, dis of die familie se geskiedenis hier doodgeloop het. Sy ouers se ontberings en verlange na 'n nuwe lewe roep; ' $n$ soort hardkoppigheid om na die horison te kyk soos húlle gemaak het. [...] In sy gemoed lê 'n leegheid, ervaar hy 'n soort vyandigheid van die land, die berg, die stoppelland. Maar eintlik weet hy dit is hy wat van alles losgeraak het. (bl. 31)

Dan besluit Johannes om na Graaff-Reinet te trek en sy broer Daniel bly agter.

Dit is die patroon wat regdeur die verhaal herhaal word: Trek, vestig, party bly agter en ander trek weer as daar teenslae of bedreiging kom. So vestig een nasaat later tussen die riviere, tussen die Modder- en Rietrivier en 'koop' 'n stuk grond by die San. Die transaksie word bekragtig en die San se aanwesigheid in die omgewing staan vas in die rotstekeninge in grotte. Maar later word daar weer getrek saam met 'n Voortrekker-groep, na Natal waar die trekkers by Bloukrans en Wenen gestuit word. Die Anglo-Boereoorlog raak die familie diep en ingrypend en weer moet hulle van voor af begin. Later gaan van die seuns van die grond tussen die riviere weg om professionele loopbane te volg. Die volgende generasie moet op die grens gaan veg en uiteindelik keer 'n jong nasaat terug en vestig hom weer op die plaas tussen die riviere. Hy besef uiteindelik dat sommige dinge onafwendbaar is, in die woorde van sy skoonvader dinge 'wat noodwendig moet gebeur omdat die saad daarvan lankal geplant is' (bl. 119). En inderdaad kom daar'n grondeis op die plaas. Hy soek dan die San-familie, van wie die grond aanvanklik gekoop is, weer op en doen navorsing om die oorspronklike dokumente op te spoor wat die wit familie en die San opgestel het. Hy verduidelik aan die San se nasaat: 'Dis vir ons twee spoorsny in 'n bos wat ons nie ken nie niemand weet wat vir ons wag nie.' (bl. 126)

Op ' $n$ manier is hierdie verhaal die verhaal van die meeste Afrikaanse Suid-Afrikaanse families. Almal kan 'n verhaal vertel wat raakpunte hiermee vertoon. Die verhaal verbeeld dus op 'n eksemplariese manier die verhaal van een komponent van die Suid-Afrikaanse gemeenskap en 'n mens sien hoe een verhaal kan help om baie ander verhale te verstaan. Vanselfsprekend is hier ook fiksionalisering ter sprake. Dit is nie presies die werklike geskiedenis van een familie nie, maar al die elemente van wat potensieel die ware verhaal van 'n Suid-Afrikaanse familie kan wees, word betrek en elke gebeurtenis het wel 'n duidelik aantoonbare korrelaat in die geskiedenis. Die tematiese ondergrond van die verhaal, soos van die geskiedenis in die algemeen, word vir die hede so verwoord:

Nou nie in kontak met die vyand nie, maar met woorde op papier - nie minder gevaarlik nie oor die verwagtinge wat geskep is, beloftes sonder nadink, leuens en arrogansie, soms vergelding. Mag is die wagwoord. Die mens se geskiedenis is deurspek van geweld, uitbuiting, onderdrukking aan die hand van gewetenlose maghebbers. (bl. 121)

Van Niekerk skryf op die man af en gee die gedagtes van elke generasie weer: die hoop, die moed, die volharding, die kommer en vrees van gewone mense met goeie eienskappe en tekortkominge. Daar is min kommentaar op die gebeure as sodanig, min dinge word as goed of sleg gemerk. Dit is asof alles net beskryf word soos dit gebeur. Op die manier ontwikkel die verhaal sy geloofwaardigheid en oortuigingskrag.

Stilisties is die teks helder en suiwer, met 'n goeie afwisseling van vertelling en uitbeelding, dialoog en pragtige beskrywings van die land en sy mense. Die boek sluit af op 'n positiewe noot, of liewer met die hoop op die aanbreek van 'n positiewer bedeling as dit wat agter lê. Die laaste gedeelte van die verhaal word in die eerste persoon vertel en die verteller wat die nuwe ooreenkoms met die afstammelinge van die San van tussen die riviere sluit, besef goed dat hy nogtans nie die mense kan inperk of vir hulle finale besluite kan neem of oor 'n lewensstyl vir hulle kan oordeel nie. Maar hy doen wat hy voel hy moet doen:

Ons neem Kousop en sy vrou na die holkrans. Dié keer kyk hy anders na die figure op klip. Dit lyk of die eland hulle aantrek hulle staar byna na die dier wat lyk of hy uit die rots wil spring. (bl. 134)

Terwyl 'n mens die verhaal lees, verwonder jy jou oor die manier waarop mense herhaaldelik na teëspoed weer opstaan en aangaan, 'n ander plan beraam, 'n ander koers inslaan. Dit was vir my asof hierdie X-straalfoto van die geskiedenis my opnuut bewus gemaak het van wat goed én problematies is in ons geskiedenis, maar veral oor die lotsverbondenheid van die mense wat nou hier leef en moet saamleef.

Kroniek van turf is mooi uitgegee deur Protea en kos R160. 